\title{
The Daily Physiotberapy Regimen in Cystic Fibrosis?
}

\section{M. DAVIDS}

\section{SUMMARY}

The aim of this paper is to question the accepted physiotherapy regimen for children with Fibrocystic Disease. Is it the most effective way of keeping the lungs clear of secretions? How much are we imposing added stress on an already stressed family? is it not possible to design a programme which reduces the stress and is socially acceptable?

The traditional physiotherapy regimen of breathing exercises, postural drainage and percussion is described. Forced expiratory technique is described as well as various forms of nebulisation.

The psychological impact on the family of a chronic, life-threatening disease, is discussed. Compliance with set physiotherapy regimens and the family's (especially the mother's) reaction to them is discussed.

The most recent literature on the effectiveness of traditional physiotherapy techniques is reviewed.

From this review as well as from personal experience, it is concluded that a rigid physiotherapy regimen is stressful and compliance is frequently poor. Suggestions are made how to overcome this. It is stressed that this paper deals with the home programme, not with the hospital programme for acute exacerbations of the disease.

\section{INTRODUCTION}

Cystic Fibrosis (CF) is the most common of the genetically determined diseases among Caucasians ${ }^{1}$ and as such is the most common cause of chronic suppurative lung disease in white children. ${ }^{2}$ The calculated heterozygote rate in Caucasians is approximately 1:20.

\footnotetext{
L. M. Davids

Control Physiotherapist, Red Cross War Memorial Children's Hospital, Rondebosch, Cape

Paper read at Congress of the South African Society of Physiotherapy, Johannesburg. April 1985
}

\section{OPSOMMING}

Die doel van hierdie eksemplaar is om die aanvaarde fisioterapie regimen vir kinders met Fibrosistiese Siekte te ondervra. Is dit die mees doeltreffende manier om die longe vry van sekresies te hou? Hoeveel ekstra spanning lê ons op 'n familie wat al reeds gespanne is? Is dit nie moontlik om 'n program te skets wat die spanning verminder en sosiaal aanvaarbaar is nie?

Die tradisionele fisioterapie regimen van asemhaling oefeninge, posturale dreinering en beklopping word beskryf. Die gedwonge ekspiratoriese tegniek sowel as verskeie vorms van nebulisasie word beskryf.

Die sielkundige slag van 'n chroniese lewens-dreigende siekte op die familie word bespreek. Die nakoming van vaste fisioterapie leefreëls en die reaksie van die familie (en veral die moeder) daartoe word bespreek.

Die mees onlangse literatuur oor die doeltreffendheid van tradisionele fisioterapie tegnieke word nagegaan.

Van hierdie oorsig asook van persoonlike ondervinding word dit afgelei dat 'n stywe fisioterapie regimen spannend is en dat nakoming dikwels swak is. Voorstelle word gemaak hoe dit oorkom kan word. Dit word beklem dat hierdie eksemplaar oor die tuis-program handel en nie oor die hospitaal-program vir akute opvlammings van die siekte nie.

The reported incidence of $\mathrm{CF}$ in white populations varies between 1:1000 to 1:7000. A particularly high incidence occurs in the descendants of the 'Dorsland Trekkers' found in South West Africa. The calculated carrier rate is $1: 12$ in this group. ${ }^{3}$

$\mathrm{CF}$ is extremely rare among South African blacks and to date no black child attends the CF clinic at the Red Cross War Memorial Children's Hospital. The incidence among the coloured community is not known but it is lower than that of the whites in South Africa. ${ }^{3}$

It is generally accepted that chest physiotherapy plays a large role in the treatment regimen for $\mathrm{CF}$ and that the improvement in the survival of these patients is in 
part due to the use of physiotherapy. ${ }^{4}$ The physiotherapist plays a very important role in the lives of $\mathrm{CF}$ children and their families.

The time has come to assess the demands we make upon the parents and the child and to consider whether we are not making life even more difficult for the families concerned. This was brought home to me when a remark made by the mother of a recently deceased child was reported to me. The child was severely affected and died at approximately 7 years of age. When this happened the mother said, "Thank goodness I don't have to do the physio any longer". It was the physiotherapy regimen demanded of this mother which seemed to her to be the worst aspect of the disease.

\section{THE TRADITIONAL PHYSIOTHERAPY REGIMEN}

This consists of postural drainage with percussion, vibration, breathing exercises and coughing.

Postural drainage consists of a variety of positions in which the patient is placed where gravity assists the drainage of secretions. According to Hodson and Gaskell ${ }^{4}$ it may take up to 15 minutes in an older child to drain any one area and several areas may need to be drained. A treatment session could last up to an hour 2-3 times a day. The child's bed needs to be tipped and/or a foam wedge may be used.

Percussion and vibration must be performed by the mother or some other member of the family. We find the use of mechanical vibrators more acceptable to both mother and child.

Coughing is done when secretions reach the larger airways. As part of the daily regimen some form of inhalation therapy is included.
1. Mucolytics
a) Mistabron 1:1. Not generally liked but the most effective mucolytic.
b) Bisolvon 1:4. Very useful in patients who have sinusitis.

2. Bronchodilators a) Ventolin $1 / 2 \rightarrow 1: 1$

b) Ipradol 1:4

Used for the children with bronchospasm.

3. After postural drainage nebulized antibiotics may be used.

At present we are using Netilmycin $75 \mathrm{mg}$ bd. This may be combined with Cárbenicillin in $1 \mathrm{~g}$ bd. Hudson disposable nebulizers are generally used.

A variety of compressors are available commercially.

\section{PSYCHOSOCIAL IMPLICATIONS}

$\mathrm{CF}$ is a chronic, fatal disease. There is no cure although life expectancy has increased as a result of improved treatment. So the problem has been extended. Each individual patient has to cope with his illness for a much longer period. ${ }^{5}$ We now have adolescents and young adults attending $\mathrm{CF}$ clinics.

Even in milder cases there are hospital admissions for acute exacerbations. There is an inevitable stress on the child and his family resulting in a varying degree of psychosocial dysfunction.

A number of studies have dealt with the impact of home treatment on the child and his family. Burton 5 found that of the whole treatment regimen from replacement enzymes to physiotherapy, it was the physiotherapy that occasioned the greatest protest from the children and the greatest dislike of administering it by the parents.

Mikkelson et al. ${ }^{6}$ found that the fact of having to treat the child daily was a constant reminder of the presence of the disease and its fatal outcome. Most parents were reluctant to admit that they found the treatment time-consuming ${ }^{7}$ and some made a conscious effort to keep so busy with the treatment to enable them to deny negative thoughts.

Most important, $\mathrm{De} \mathrm{Wet}^{7}$ found that the parents tended to overestimate the effects of their home treatment in both a negative and a positive way. "When the patient was healthy it was seen as a result of persevering with treatment. Alternatively when the patient was ill this was seen as a failure on their part. Deterioration was seldom ascribed to the normal course of the illness".

Recent studies show that on the whole children are coping relatively well with life and emotional disturbance is not an inevitable outcome of the disease. ${ }^{8}$ Bywater ${ }^{9}$ found that it was the mothers who have a significant tendency towards depression. The fathers seem to escape this possibly because they are employed outside the home and are not continually reminded of the disease.

We find at the Red Cross War Memorial Children's Hospital that the children of the lower socio-economic groups show minimal compliance with a physiotherapy regimen. If the child dislikes it, treatment is stopped. Also, understanding of the implications of the disease is slight and few mothers seem sufficiently concerned to learn more about the condition.

\section{STUDIES ON CHEST PHYSIOTHERAPY}

Chest physiotherapy is an accepted part of the treatment regimen for CF. In the last 10 years the real benefits of this time-consuming treatment have been the subject of a number of studies.

1. Pryor and Webber ${ }^{10}$ evaluated the forced expiration technique (FET) and found it produced more secre tions in a shorter period of time than conventional percussion and vibrations. It was done in conjunction with postural drainage, there being no attempt to separate the two techniques. The patients preferred FET and as it was performed by themselves it made them independent of outside help.

2. Wong et al." proved that gravity does affect the mucus transport rate in CF in the trachea. Although they recommend postural drainage there is still no indication of whether the mucus transport rate is affected in the smaller airways or-whether the variety of postural drainage positions is necessary.

3. Desmond et al.12 performed a long-term trial on well CF patients. They found that regular chest physiotherapy gave little immediate functional improvement but a 3 week period without physiotherapy led to a worsening of functional status. 
These patients all had mild to moderate airflow obstruction. The deterioration was reversed after regular chest physiotherapy was resumed.

4. A study done in Denmark by Anderson et al. ${ }^{13}$ considered the effect of positive expiratory pressure (PEP) on the amount of sputum produced and on the skin oxygen tension $\left(\mathrm{P}_{\mathrm{s}} \mathrm{O}_{2}\right)$. It was found that the use of PEP with or without postural drainage produced the largest amounts of sputum and that the $\mathrm{P}_{\mathrm{s}} \mathrm{O}_{2}$ was significantly increased by the use of PEP without postural drainage. Conventional chest physiotherapy decreased the $\mathrm{P}_{\mathrm{s}} \mathrm{O}_{2}$ and produced considerably less sputum. Treatment time was halved when postural drainage was excluded. FET was used throughout to help remove secretions.

5. A study by Rossman et al. ${ }^{14}$ used Xenon scans to demonstrate lung clearance and found that vigorous regimented cough sessions (in sitting) were as effective for clearing secretions as therapist administered physiotherapy. This is one of the few studies to control for cough alone. The secretions cleared were principally in the large airways.

A number of studies have been done to investigate the use of exercise instead of or as an adjunct to chest physiotherapy. The children chosen for these studies were not severely affected and could cope with exercise programmes. Swimming was found to be particularly helpful.

6. Zach et al. ${ }^{15}$ found that mucus clearance increased on swimming days and that there was improved ventilatory function. Daily physiotherapy was continued. Previously Keens et al. ${ }^{16}$ proved that ventilatory muscle endurance could be improved by specific ventilatory muscle endurance training or upper body endurance exercises.

7. A year later Zach et al. ${ }^{17}$ compiled a total training programme of vigorous physical exercise and sport. This lasted for 17 days and no physiotherapy was given. There was a marked improvement in the peak expiratory flow rate which was maintained after the programme had ended. It was also noted that the frequency of coughing and volume of expectorated sputum reached a maximum between $3-5$ days and then decreased to become slight by the end of the programme.

8. Orenstein et al. ${ }^{18}$ ran an exercise trial consisting principally of jogging. At the end of 3 months they found a significant improvement in exercise tolerance. There was also a greater clearance of secretions. They considered that exercise was as effective as physiotherapy in the removal of secretions. Orenstein stresses that only children with a vital capacity or FEV, of more than $50 \%$ of the expected norm should do this type of exercise. Also until more trials have been done he is wary of prescribing exercise instead of physiotherapy.

\section{DISCUSSION}

The static physiotherapy regimen of postural drainage, percussion, vibrations and intermittent coughing is coming under fire from all quarters. If done properly this treatment is extremely time-consuming and not particularly comfortable. Small children hate to remain still for any length of time and the older ones become bored. The onus of carrying out the treatment generally falls on the mother and dispute over the treatment adds to the stress of having a child with a lethal dose.

Physiotherapy is aimed at mobilizing and removing secretions from the lungs. It cannot prevent acute lung infection. It cannot prevent eventual deterioration of the lung tissue. It does not improve lung function. What we can do is to normalize the child's life as much as possible within the limits of the condition.

From various studies it can be seen that there are a number of ways to mobilize secretions which take less time and are less constricting to the child and the mother. Also as the child gets older he would be able to perform his treatment independently. General exercise, swimming, jumping, etc. all mobilize secretions. Breathing sessions with a PEP mask mobilize secretions. Directed cough both moves and removes secretions from the large airways and the trachea.

Teaching coughing is perhaps the most important aspect of the physiotherapist's advice to parents. This is frequently neglected, far more time being spent on postural drainage and percussion. It is possible to teach a child of two years to cough and expectorate. The sooner the child can do this the better. It obviates the trauma of being suctioned for regular sputum specimens and ensures that the child will cough effectively.

If parents are non-compliant with treatment the physiotherapist should organize regular attendance at the Physiotherapy Department. Here the child can be taught to do the treatment himself. Obviously the simpler and more enjoyable the prescription the greater the likelihood there will be of keeping the chest clear.

It must be emphasized that the physiotherapy regimen has to be planned individually for each child and family. The children who are severely affected cannot live such an active life and will require a more conventional type of programme. The children must also be prepared for hospital admissions because activity there is usually limited by drips. Although it is the parents' responsibility to see that the child clears his secretions regularly they should always feel free to come to the Physiotherapy Department whenever they need advice.

\section{CONCLUSION}

Physiotherapy forms an essential part of the life of a CF patient. In order to ensure as normal a childhood and adolescence as possible we must be more dynamic in our approach. We must try to lighten the burden on the family and yet be as effective as possible.

\section{References}

1. Holzel A. The quest for the basic defect in Cystic Fibrosis. Physiotherapy 1975; 61(8): 238-239.

2. Lipow HW and McQuitty JC. Cystic Fibrosis. In: Rudolf AM, ed. Pediatrics, Norwalk, Connecticut: AppletonCentury-Crofts, 1982; 1433-1440. 
3. Hill ID and Bowie MD. Cystic Fibrosis. Modern Medicine $1984 ; 9$ : 77-86.

4. Hodson ME and Gaskell DV. Physiotherapy. In: Hodson ME, Norman AP and Batten JC, eds. Cystic Fibrosis. London: Baillière Tindall, 1983; 219-24l.

5. Burton L. The family life of sick children. London: Routledge \& Kegan Paul, 1975; 3,95.

6. Mikkelson C, Waechter E and Crittenden M. Cystic Fibrosis: a family challenge. Children Today 1978; 7(4): 22-26.

7. De Wet $B$. The birth of a child with a congenital anomaly: some psychosocial implications for the family. December 1984. Dissertation for PhD at University of Stellenbosch, p303.

8. Drotar D et al. Psychosocial functioning of the child with cystic fibrosis. Pediatrics 1981; 67(3): 338-343.

9. Bywater EM. Adolescents with cystic fibrosis: psychosocial adjustment. Arch Dis Child 1981; 56: 538-543.

10. Pryor JA and Webber BA. An evaluation of the forced expiration technique as an adjunct to postural drainage. Physiotherapy 1979; 65(10): 304-307.

II. Wong LW et al. Effects of gravity on tracheal mucus transport rates in normal subjects and in patients with cystic fibrosis. Pediatrics 1977; 60(2): 146-152.

12. Desmond KJ et al. Immediate and long-term effects of chest physiotherapy in patients with cystic fibrosis. $J$ Pediatr 1983; 103(4): 538-542.

13. Anderson JB et al. Improving the ketchup bottle method with positive expiratory pressure, PEP. 1982-1983; study done at Herlev Hospital, Denmark.
14. Rossman CM et al. Effect of chest physiotherapy on the removal of mucus in patients with cystic fibrosis. $\mathrm{Am}$ Rev Respir Dis 1982; 126(1): 131-135.

15. Zachs MS et al. Effect of swimming on forced expiration and sputum clearance in cystic fibrosis. Lancet 1981; ii: $1201-1203$.

16. Keens TG et al. Ventilatory muscle endurance training in normal subjects and patients with cystic fibrosis. Am Rev Respir Dis 1977; 116: 853-860.

17. Zach MS et al. Cystic fibrosis: physical exercise versus chest physiotherapy. Arch Dis Child 1982; 57: 587-589.

18. Orenstein DM et al. Exercise and cystic fibrosis. The Physician and Sports Medicine 1983; 11(1): 57-63.

Further reading

1. Cerny FJ et al. Hospital therapy improves exercise tolerance and lung function in cystic fibrosis. $\mathrm{Am} \mathrm{J} \mathrm{Dis} \mathrm{Child}$ 1984; 138(3): 26I-265.

2. Cystic Fibrosis Foundation. Guide to Diagnosis and Management of Cystic Fibrosis. Atlanta, Georgia, 1971. I

3. Maxwell M. Review of literature of physiotherapy in cystic fibrosis. Physiotherapy 1980; 66(7): 245-246.

4. Miot A. Cystic fibrosis and the role of the physiotherapist. South African Journal of Physiotherapy 1981; 37(3): 72-74.

5. Travis G. Chronic illness in children. Stanford: Stanford University Press, 1976.
For Orthopaedic Appliances,

Surgical corsets,

Cervical collars,

Children's shoes \& boots,

Artificial limbs,

Latest in plastic modification.

For Hiring and selling of

Hospital Equipment and

Sick room requisites -

Wheel chairs, walking aids,

Commodes,

Hospital beds.

Traction apparatus

Visit the orthopaedic mechanicians

\section{A. C. MILLER \& Co.}

Technicians registered with the S.A. Medical and Dental Council

\section{BREE STREET JOHANNESBURG}

Telephone (011) 337-4763

P.O. Box 3412 Johannesburg

\section{Try New Flotation Pads to keep you free from bedsores}

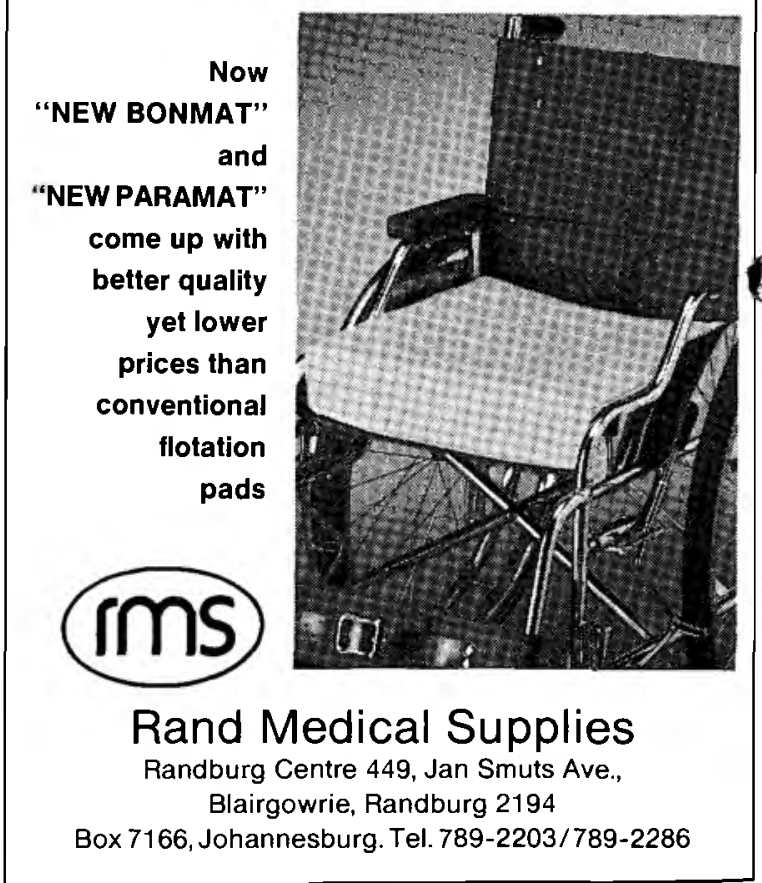

